\title{
Compared sensitivity of species, genera and families of Molluscs to biodegradable pollution
}

\author{
J. Mouthon ${ }^{1}$ \\ S. Charvet ${ }^{1}$
}

Keywords : molluscs, level of taxonomic identification, pollution, rivers.

A scale of sensitivity of mollusc species to biodegradable pollution was proposed in a previous paper (Mouthon 1996). Using these results as a basis, and introducing supplementary elements in a correspondence analysis, we have been able to formulate a scale of sensitivity of mollusc genera and families. A quantification of information lost when using genus or family-level rather than species-level identification was carried out by calculating the Euclidean distances between each species and the gravity centre of the genus and family to which it belongs. The results obtained showed that the genus-level identification can constitute an acceptable compromise for using molluscs as water quality indicators in biomonitoring.

Sensibilité comparée des espèces, genres et familles de mollusques aux pollutions biodégradables

Mots-clés : mollusques, niveau de détermination, pollution, cours d'eau.

Une échelle de sensibilité des espèces de mollusques aux pollutions biodégradables a été proposée dans un précédent article (Mouthon 1996). A partir de ces résultats et grâce à l'introduction dans l'analyse des correspondances d'éléments supplémentaires, représentés par les moyennes des effectifs des espèces appartenant au même genre, puis à la même famille, nous avons pu en déduire une échelle de sensibilité des genres et des familles de mollusques. Une estimation de l'importance de l'information perdue lorsque l'on identifie les mollusques à la famille ou au genre au lieu de l'espèce a été effectuée grâce au calcul de distances euclidiennes entre chaque espèce et le centre de gravité du genre ou de la famille auxquels elle appartient. Les résultats montrent que, si l'on veut intégrer les mollusques aux indicateurs de qualité d'eau, lè genrè pourrait constituer un compromis acceptable.

\section{Introduction}

Choosing the level of determination in the framework of ecological studies of benthic macro-invertebrate communities in rivers is still a topical subject (Bournaud 1996, Bowman \& Bailey 1997). The arguments of those who defend the species for which "species-level identifications are necessary" and the partisans of using a higher level of determination (genus,

1. Cemagref, 3bis quai Chauveau, CP 220, F - 69336 Lyon Cedex 09 , France. family), i.e. "higher taxonomic levels are accepted" have been set out clearly by Resh \& Mc Elravy (1993). Although this choice mostly depends on the competencies of the specialists working in the laboratory, it can also be decided by the biological index determination protocol applied to detecting the degradation of running water quality, for example, the Biological Monitoring Working Party score (BMWP) used in the United Kingdom (ISO 1979) or "l'Indice Biologique de Qualité Générale" (IBG) (Verneaux 1982), and its standardised version used in France, IBGN (AFNOR 1992). On the basis of a scale of sensitivity of mollusc species to biodegradable pollution formulated during a previous study (Mouthon 1996), we therefore propose to : 
- define the range of pollution sensitivity of mollusc genera and families ;

- show the quantity of information lost by using genus or family-level instead of species-level identification when interpreting a mollusc community's tolerance to pollution.

\section{Material and methods}

Malacological samplings were made at 160 stations belonging to 5 major French river basins and at different coastal rivers in the South of France. Simultaneously, physico-chemical analyses were carried out at these same sites by the Water Agencies within the framework of a national inventory of the degree of pollution of surface waters. Six variables were chosen. These are dissolved oxygen (DO), the biochemical demand for oxygen $\left(\mathrm{BOD}_{5}\right)$, ammonia $\left(\mathrm{NH}_{4}{ }^{+}\right)$, nitrites $\left(\mathrm{NO}_{2}{ }^{-}\right)$, Kjeldhal's nitrogen (NKJ) and orthophosphates $\left(\mathrm{PO}_{4}{ }^{3-}\right)$.

The molluscs were sampled by using a rectangular hand net $(25 \times 18 \mathrm{~cm})$, fixed in-the-field with neutral formaldehyde. The samples were sieved at $630 \mu \mathrm{m}$ in the laboratory and identified using a binocular microscope. The numbers of species collected over a surface area from 0.5 to $3 \mathrm{~m}^{2}$ were then expressed per square meter. After transformation into classes, the physicochemical and malacological data were processed using different softwares: Correspondence Analysis (CA) and Hierarchical Ascending Classification (HAC) (Benzecri 1976) taken from the ADDAD library (for further details see Mouthon 1996).

The systematic nomenclature used is that recommended by the Limnofauna Europea (Willman \& Pieper 1978). Nevertheless, regarding the Lymnaeidae family we chose the classification recently proposed by Glöer \& Meier-Brook (1994), close to that already defined by Germain (1931). The 48 species making up the basic material of this article belong to 30 genera which are distributed within 13 families (Table 1). Lymnaea 'palustris' refers to the former name and perhaps groups several species (Falniowski 1980).

\section{Results}

In a previous study, a table featuring the average numbers of each species obtained for each class of 6 physico-chemical variables was processed using Correspondence Analysis (Mouthon 1996). The results obtained distinguished, on the one hand, pollution resistant species (more or less closely associated with classes 5, 4 and 3 of the physico-chemical variables), and on the other hand, species displaying good affinity with only slightly or not degraded stations (located within proximity of classes 1 and 2 of these variables). According to the Hierarchical Classification (HAC), these two major categories of species are composed of respectively 8 and 5 groups. Projection in the factor map F1F2 of these groups in the form of ellipses of inertia permitted estimating the sensitivity or tolerance of species to biodegradable pollution, and proposing a range of freshwater mollusc pollution sensitivity.

By using this scale of species pollution sensitivity (Mouthon 1996), it is possible to deduce the sensitivity of mollusc genera and families by using them as supplementary elements, i.e. non-active individuals affected by a null weight. These elements, added to the initial data matrix, are represented by the averages of numbers of species belonging to the same genus and then to the same family. After projection in the factor map F1F2 of the species analysis of these additional individuals, the position of each genus or family finds itself at the gravity centre (barycentre) of the pointsspecies which compose it (Figs 1,2). In the second stage, the result of adding these supplementary elements to the species classification and to the ellipses of inertia (cf. Mouthon 1996), shown in figure 3, provides us with a classification of genera and families as a function of their sensitivity to biodegradable pollution.

By observing the position in the factor map F1F2 and in the classification of mono-specific genera, it can be seen that most of them ( 23 out of 30 ), and the mono-specific families (4 out of 13), correspond to that of the species which they represent. By contrast; the 7 pluri-specific genera (counting 23 species) and the 9 pluri-specific families (26 genera and 44 species) occupy positions related to the pollution sensitivity of the species which compose them (Figs 3, 4).

In order to quantify information lost by using genus or family-level instead of species-level identification. we calculated, for the first four factors representing $56.3 \%$ of the total inertia, the Euclidean distance of each species from the gravity centre of the genus and of the family to which it belongs. The values of these distances were then converted into 5 classes (Table 2). These were defined by dividing into five equal parts the distance obtained between Pisidium casertanum and the gravity centre of the family Sphaeriidae, the highest value after that of Myxas glutinosa and the gravity centre of the Lymnaeidae, not chosen due to its scarcity (cf. discussion). The classes obtained for each species are shown in the figure 4.

The affinity for degraded situations shown by Radix peregra and by R.auricularia is quite close and the distance of these two species from the gravity centre re- 
Table 1. List and number of taxa used.

Tableau 1. Liste et nombre des taxons utilisés.

\begin{tabular}{|c|c|c|c|c|}
\hline GASTROPODS & Family & Genus & $\begin{array}{c}\text { number } \\
\text { of species }\end{array}$ & $\begin{array}{c}\text { number of species } \\
\text { per family }\end{array}$ \\
\hline & Bithyniidae & Bithynia & 2 & 2 \\
\hline & Hydrobiidae & Potamopyrgus & 1 & 2 \\
\hline & & Belgrandia & 1 & \\
\hline \multirow[t]{9}{*}{ Prosobranchia } & Neritidae & Theodoxus & 1 & 1 \\
\hline & Viviparidae & Viviparus & 1 & 1 \\
\hline & Valvatidae & Valvata & 2 & 2 \\
\hline & Acroloxidae & Acroloxus & 1 & 1 \\
\hline & Ancylidae & Ancylus & 1 & 2 \\
\hline & & Ferrissia & 1 & \\
\hline & Lymnaeidae & Galba & 1 & $6 ?$ \\
\hline & & Myxas & 1 & \\
\hline & & Lymnaea & 1 & \\
\hline \multirow[t]{10}{*}{ Pulmonata } & & Radix & 2 & \\
\hline & & Stagnicola & $1 ?$ & \\
\hline & Physidae & Physa & 1 & 2 \\
\hline & & Physella & 1 & \\
\hline & Planorbidae & Anisus & 1 & 6 \\
\hline & & Armiger & 1 & \\
\hline & & Bathyomphalus & 1 & \\
\hline & & Gyraulus & 1 & \\
\hline & & Hippeutis & 1 & \\
\hline & & Planorbis & 1 & \\
\hline \multirow[t]{8}{*}{ BIVALVES } & Dreissenidae & Dreissena & 1 & 1 \\
\hline & Sphaeriidae & Musculium & 1 & 15 \\
\hline & & Pisidium & 11 & \\
\hline & & Sphaerium & 3 & \\
\hline & Unionidae & Anodonta & 2 & 7 \\
\hline & & Potomida & 1 & \\
\hline & & Pseudanodonta & 1 & \\
\hline & & Unio & 3 & \\
\hline
\end{tabular}




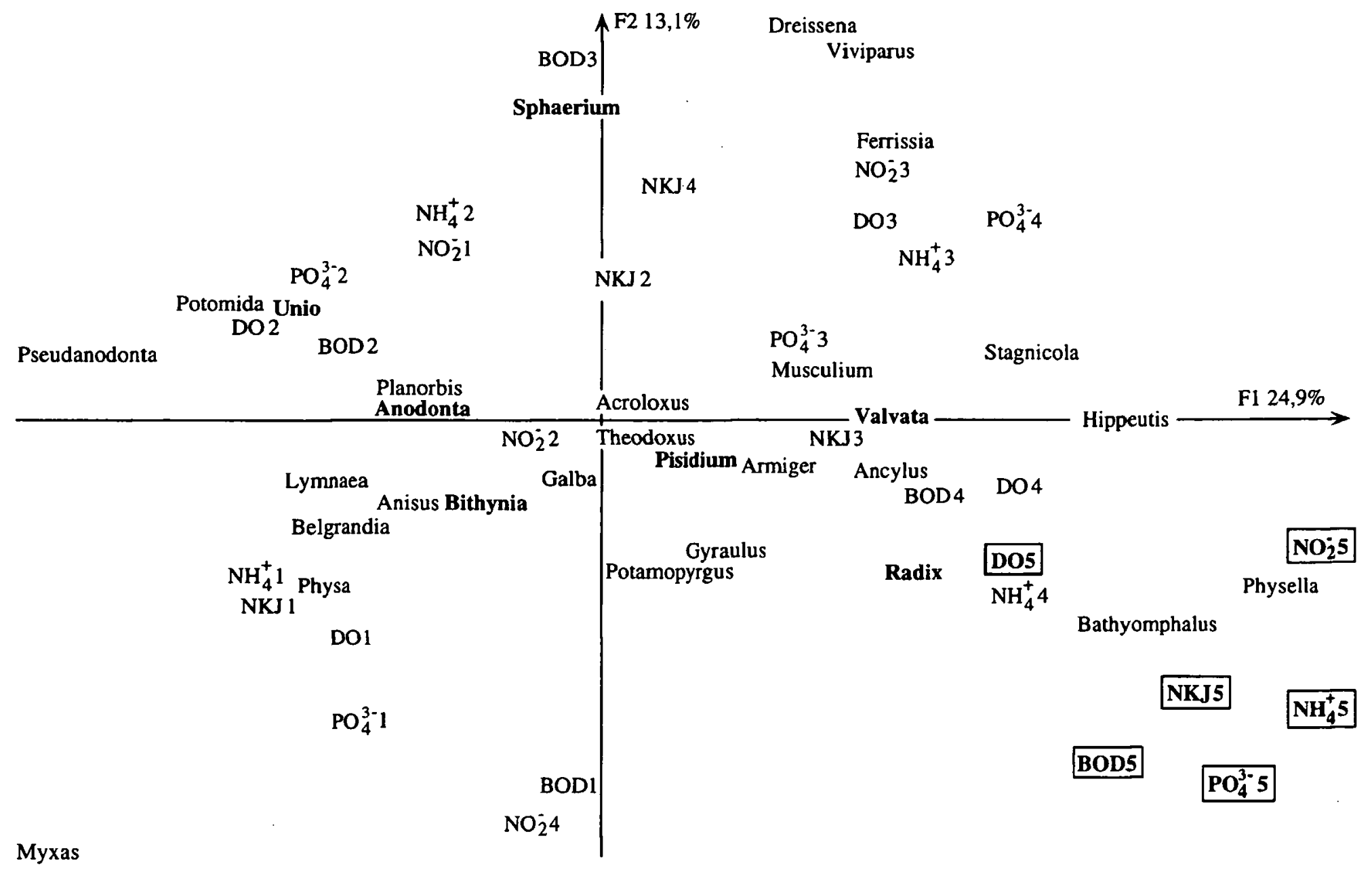

Fig. 1. Projection of supplementary elements (GENUS) in the factor map F1F2 of species correspondence analysis (see Mouthon 1996). (Monospecific genera are in normal characters, multi-specific genera are in bold type).

Fig. 1. Projection dans le plan factoriel des éléments supplémentaires (GENRES). Les axes F1F2 sont ceux de l'analyse des correspondances des espèces. (Les genres monospécifiques sont en caractère normal, les genres plurispécifiques sont en caractère gras).

presenting the genus Radix is very reduced (Fig. $4 \mathrm{~A}$ ). Consequently, the position of the latter also tends to indicate high tolerance to biodegradable pollution. Likewise, the sensitivity of genus Unio is quite close to that of the three species making up this genus (Fig. 4 B). In these two cases, taking into account the genus-level instead of the species-level results in only a slight loss of information on pollution tolerance. On the contrary, species belonging to the genera Valvata, Bithynia, Sphaerium, Pisidium and to the pluri-specific families can demonstrate sometimes very different sensitivities to biodegradable pollution. Thus, of the two species of Physidae, very distant from the gravity centre represented by this family, Physella acuta is very tolerant, while Physa fontinalis, is rather sensitive (Fig. 4 B). However, overall, this family is classified among most resistant to pollution. The same phenomenon can be observed for the Bithyniidae and the Hydrobiidae, but this time these two families are considered as being rather sensitive to biodegradable pollution (Figs $4 \mathrm{~B}$ and
C). Within the genera Valvata, Bithynia, Sphaerium and Pisidium or the families of Ancylidae, Valvatidae and even more in those of the Bithyniidae, Lymnaeidae, Planorbidae and Sphaeriidae, species are found presenting sometimes very different degrees of sensitivity or tolerance. Under these conditions, considering the overall pollution sensitivity of the genus rather than that of the species results in a significant loss of information. This only concerns a minority of genera but more than half the families.

\section{Discussion}

Applying these results to the interpretation of faunistic lists whose use genus or family-level identification gives rise to several observations, in particular with respect to the geographic distribution, frequency and habitat of certain species. Physa fontinalis is found essentially in the northern half of France. On the other hand, Physella (Physa) acuta which occupied only the 


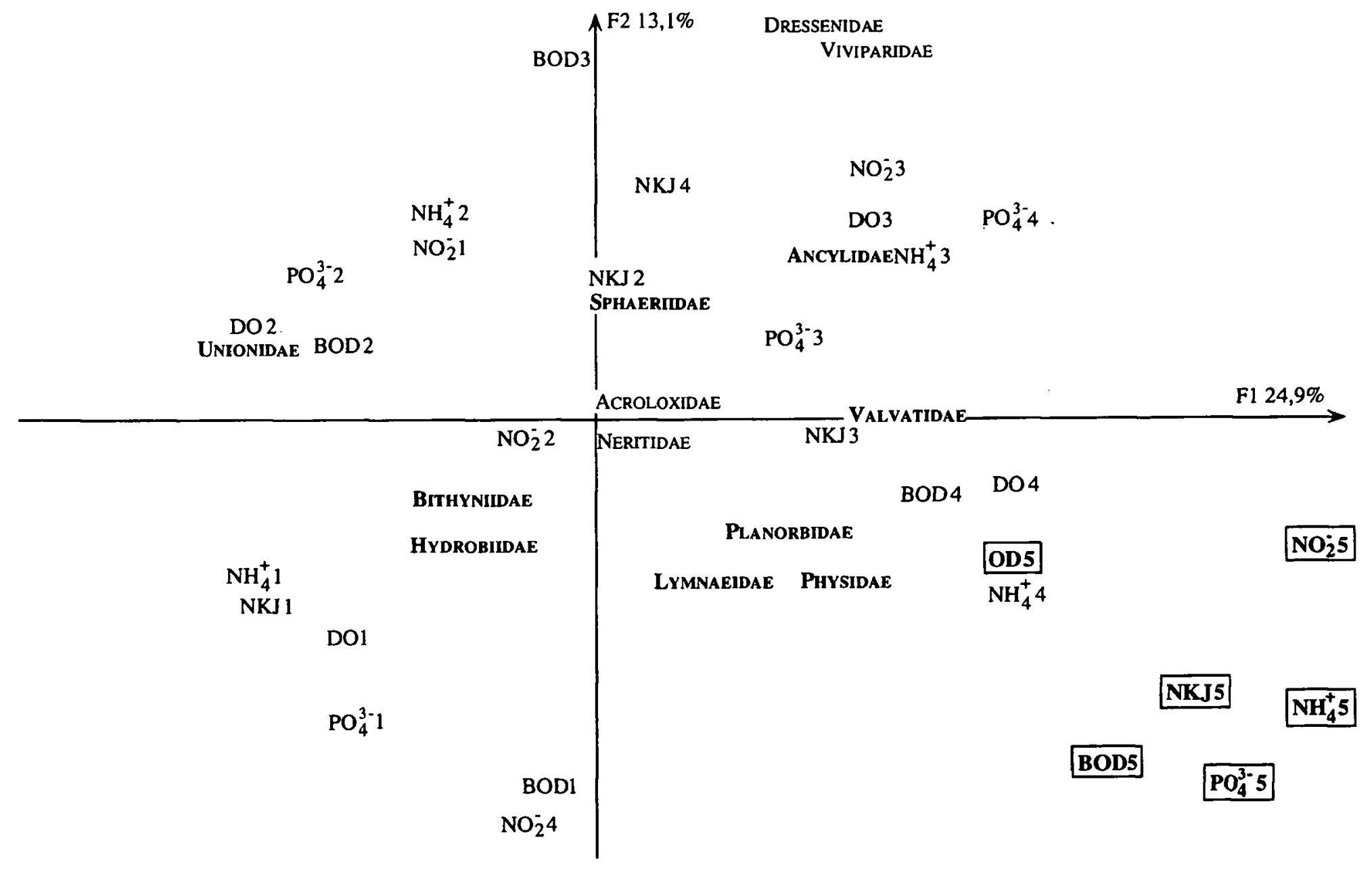

Fig. 2. Projection of supplementary elements (FAMILIES) in the factor map F1F2 of species correspondence analysis (see Mouthon 1996). (Mono-specific families are in normal characters, multi-specific families are in bold type).

Fig. 2. Projection dans le plan factoriel des éléments supplémentaires (FAMILLES). Les axes F1F2 sont ceux de l'analyse des correspondances des espèces. (Les familles monospécifiques sont en caractère normal, les familles plurispécifiques sont en caractère gras).

southern half of France at the beginning of the century (Germain 1931) has now colonized the entire country. Consequently, in the southern half of France, the pollution sensitivity of the family of Physidae is confused with that of Physella acuta (Fig.3).

In our study, the family of Hydrobiidae only includes the two genera Potamopyrgus and Belgrandia. The first is very frequent and found in nearly the whole France. The second is limited to the southern part of the country (Germain 1931), but particularly well represented in springs and small rivers in the south-east. Outside this southern area, and with the exception of springs where other Hydrobiidae belonging to the genus Bythinella can be found, it is possible to assimilate the pollution sensitivity of Hydrobiidae with that of Potamopyrgus antipodarum (Fig. 3).

The family Bithyniidae and the genus Bithynia are represented by two species. B.tentaculata is widespread throughout France and is quite resistant to pollu- tion ; B.leachi is not very frequent (Mouthon 1994) and pollution sensitive. Although its area of distribution is not well known, it seems, however, limited to the north of the country. Consequently, in the great majority of cases the family of Bithyniidae, essentially represented by B.tentaculata, should be considered as a rather tolerant taxon (Fig. 3).

According to Germain (1931), Myxas glutinosa is a "species of the plains living nearly everywhere in France, except in the south-east, but not common". A recent study of mollusc species frequency showed that this gastropod has become quite rare (Mouthon 1994). Its withdrawal from the analysis modifies only slightly the position of the family Lymnaeidae in the factor map F1F2 and does not change its degree of tolerance defined by the classification.

The knowledge of the longitudinal distribution and habitat of species can also be used to interpret the pollution sensitivity of certain families and genera. In- 
SPECIES

GENUS

FAMILIES

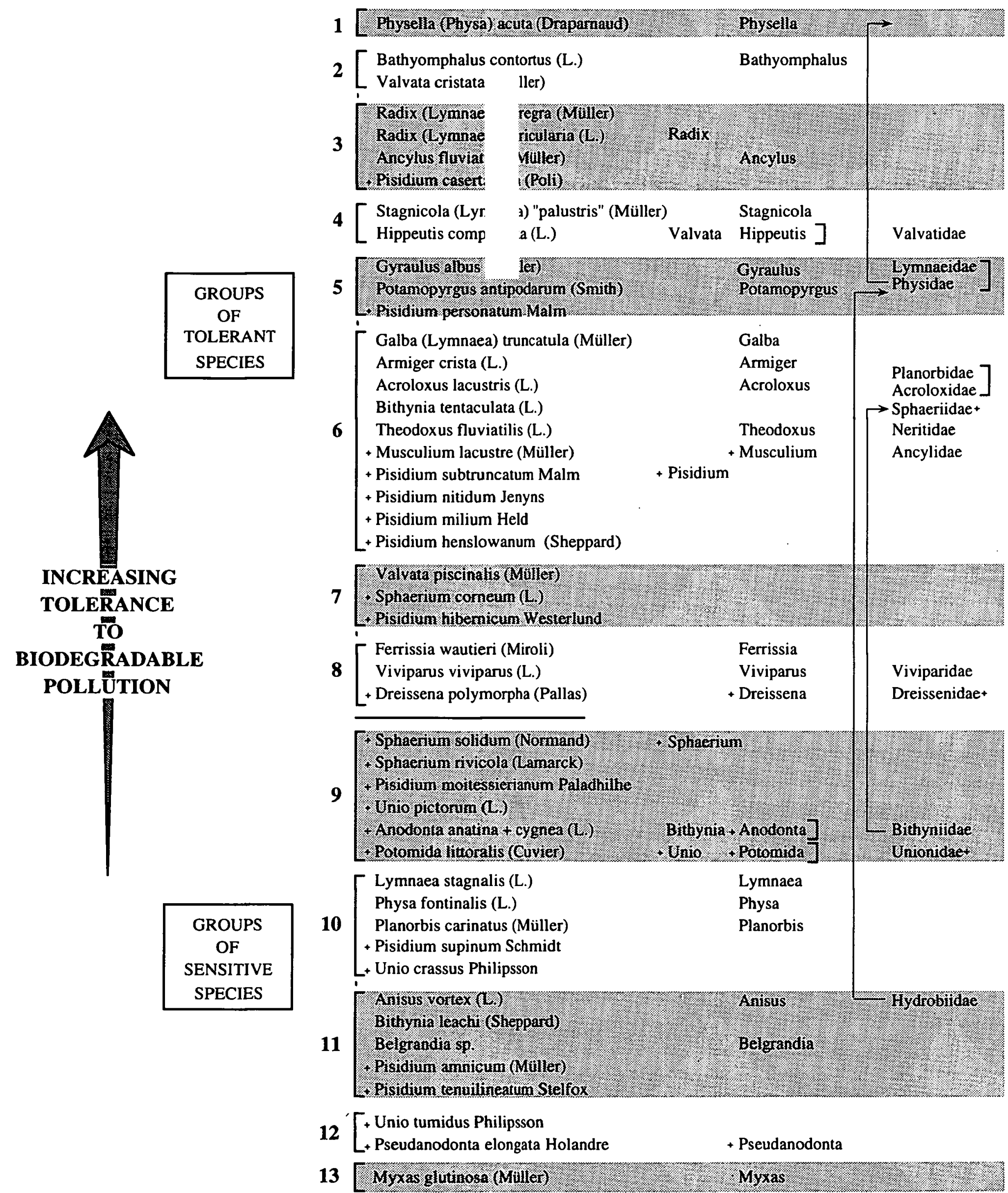

Fig. 3. Range of sensitivity of mollusc species, genera and families to biodegradable pollution according to the hierarchical ascending classification (HAC). (The bivalves are indicated by a + ; for more information see the text).

Fig. 3. Echelle de sensibilité aux pollutions biodégradables des espèces, genres et familles de mollusques définies à partir de la CAH. (Les espèces de bivalves sont signalées par un + ; pour plus d'information voir le texte). 

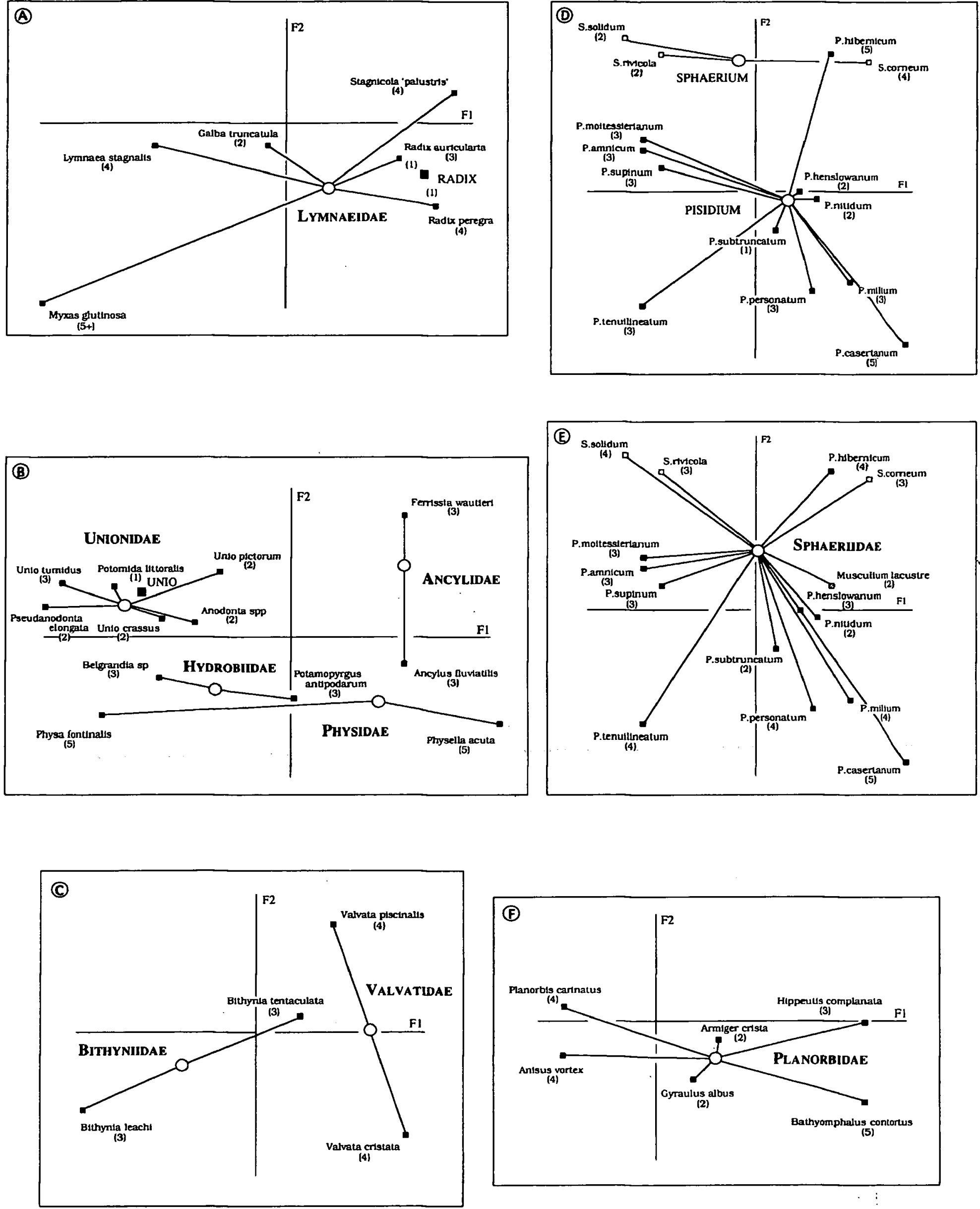

Fig. 4. Differences of sensitivity of species belonging to the same genus or the same family. The factor map F1F2 is this one of species correspondence analysis. (Classes of Euclidean distances are in brackets).

Fig. 4. Différences de sensibilité des espèces appartenant au même genre ou à la même famille. Le plan factoriel F1F2 est celui de l'analyse des correspondances des espèces. (Les classes de distances euclidiennes sont entre parenthèses). 
Table 2. Euclidean distances of species from the gravity center of the genus (distance $\mathrm{Sp}-\mathrm{G}$ ) and family (distance Sp-F) to which they belong. (1) For more explanations about this species see the text.

Tableau 2. Distances euclidiennes séparant les espèces des centres de gravité du genre (distance $\mathrm{Sp}-\mathrm{G}$ ) et de la famille (distance $\mathrm{Sp}-\mathrm{F}$ ) auquels elles appartiennent.

\begin{tabular}{|c|c|c|c|c|}
\hline species & \multicolumn{2}{|c|}{$S p-G$} & $\begin{array}{r}\text { distance } \\
\mathrm{S}\end{array}$ & $S p-F$ \\
\hline Theodoxus fluviatilis & 0 & 0 & 0 & 0 \\
\hline Viviparus viviparus & 0 & 0 & 0 & 0 \\
\hline Valvata piscinalis & 678 & 3 & 678 & 3 \\
\hline Valvata cristata & 668 & 3 & 668 & 3 \\
\hline Potamopyrgus antipodarum & 0 & 0 & 422 & 2 \\
\hline Bithynia leachi & 0 & 0 & 458 & 2 \\
\hline Bithynia tentaculata & 0 & 0 & 458 & 2 \\
\hline Belgrandia sp. & 0 & 0 & 473 & 2 \\
\hline Myxas glutinosa & 0 & 0 & 1403 & $5(1)$ \\
\hline Physella acuta & 0 & 0 & 859 & 4 \\
\hline Physa fontinalis & 0 & 0 & 900 & 4 \\
\hline Lymnaea stagnalis & 0 & 0 & 721 & 3 \\
\hline Stagnicola -"palustris" & 0 & 0 & 760 & 4 \\
\hline Galba truncatula & 0 & 0 & 227 & 1 \\
\hline Radix auricularia & 143 & 1 & 582 & 3 \\
\hline Radix peregra & 138 & 1 & 633 & 3 \\
\hline Bathyomphalus contortus & 0 & 0 & 898 & 4 \\
\hline Gyraulus albus & 0 & 0 & 272 & 1 \\
\hline Armiger crista & 0 & 0 & 302 & 1 \\
\hline Hippeutis complanata & 0 & 0 & 568 & 3 \\
\hline Planorbis carinatus & 0 & 0 & 650 & 3 \\
\hline Anisus vortex & 0 & 0 & 670 & 3 \\
\hline Ancylus fluviatilis & 0 & 0 & 546 & 3 \\
\hline Ferrissia wautieri & 0 & 0 & 559 & 3 \\
\hline Acroloxus lacustris & 0 & 0 & 0 & 0 \\
\hline Anodonta anatina+cygnaea & 0 & 0 & 361 & 2 \\
\hline Potomida littoralis & 0 & 0 & 71 & 0 \\
\hline Pseudanodonta elongata & 0 & 0 & 407 & 2 \\
\hline Unio crassus & 282 & 1 & 248 & 1 \\
\hline Unio pictorum & 344 & 2 & 345 & 2 \\
\hline Unio tumidus & 454 & 2 & 493 & 2 \\
\hline Dreissena polymorpha & 0 & 0 & 0 & 0 \\
\hline Pisidium amnicum & 535 & 3 & 535 & 3 \\
\hline Pisidium casertanum & 891 & 4 & 1045 & 5 \\
\hline Pisidium henslowanum & 356 & 2 & 472 & 2 \\
\hline Pisidium hibernicum & 846 & 4 & 752 & 4 \\
\hline Pisidium milium & 458 & 2 & 678 & 3 \\
\hline Pisidium moitessierianum & 622 & 3 & 491 & 2 \\
\hline Pisidium nitidum & 286 & 1 & 340 & 2 \\
\hline Pisidium personatum & 474 & 2 & 628 & 3 \\
\hline Pisidium subtruncatum & 97 & 0 & 372 & 2 \\
\hline Pisidium supinum & 602 & 3 & 535 & 3 \\
\hline Pisidium tenuilineatum & 601 & 3 & 818 & 4 \\
\hline Sphaerium corneum & 687 & 3 & 619 & 3 \\
\hline Sphaerium solidum & 375 & 2 & 664 & 3 \\
\hline Musculium lacustre & 0 & 0 & 309 & 1 \\
\hline Sphaerium rivicola & 381 & 2 & 616 & 3 \\
\hline
\end{tabular}


deed, Ancylus fluviatilis and Ferrissia wautieri of the family of Ancylidae, occupy very different habitats in rivers. The first one, rheophilous, lives mostly in running sectors from the rhithral to the potamal ; the second one, only develops in the calm waters of potamal. Of the three species of the genus Sphaerium, S.solidum and S.rivicola are essentially potamic. However, S.corneum colonizes both the rhithral and the potamal (Mouthon 1981, 1999). According to the types of rivers sampled it is possible to consider Ancylus fluviatilis or Sphaerium corneum rather than the less tolerant sensitivities of the family of Ancylidae or the genus Sphaerium.

Generally, the greater the sensitivity of species belonging to the same genus or to the same family, then the greater the information lost when seeking to estimate the pollution sensitivity of a genus or family. Between the two species of Radix, as between the three species belonging to the genus Unio, the difference of sensitivity is reduced. On the contrary, the difference of sensitivity between species belonging to the genera Valvata, Bithynia, Sphaerium, Pisidium or to all the pluri-specific families is considerable, thus the loss of information is significant.

Several species such as Margaritifera margaritifera (family Margaritiferidae) and Bythinella spp. (Hydrobiidae), which colonize specific biotopes, are considered as sensitive (Kolkwitz \& Marsson 1909, Björk 1962, Slàdecek 1973, Bauer et al. 1980, Mouthon 1981, Nagel 1989). On the contrary, for other molluscs such as the invasive species Menetus dilatatus (Planorbidae), Lithoglyphus naticoïdes (Lithoglyphidae) and Corbicula spp. (Corbiculidae), their tolerances to biodegradable pollution remain to be defined.

A classification can then be made on the basis of species, genera and families in order to integrate this fauna in water quality indicators which, according to the taxonomic level desired, provide more or less accurate indications. Thus, we pass from 13 (species) to 12 (genera), then to 6 (families) classes of bio-indication. The genus could constitute a possible compromise.

\section{Acknowledgments}

The authors thank Prof. J. Verneaux (University of Besançon, France) for his valuable advice.

\section{References}

AFNOR. 1992. - Détermination de l'indice biologique global normalisé (IBGN), NF T 90-35 : 9p.

Bauer G., Schrimpff E., Thomas W. \& Herrman R. 1980. — Zusammenhänge zwischen dem Bestandsrückgang der Flussperlmuschel (Margaritifera margaritifera) im Fichtelgebirge und der Gewässerbelastung. Arch.Hydrobiol., 88 : 505-513.

Benzecri J.P. 1976. - L'analyse des données - L'analyse des correspondances. Dunod (ed.) Paris : 616p.

Björk S. 1962. - Investigations on Margaritifera margaritifera and Unio crassus. Acta Limnologica, 4 : 1-109.

Bournaud M., Cellot B., Richoux P. \& Berrahou A. 1996. - Macroinvertebrate community structure and environmental characteristics along a large river : congruity of patterns for identification to species or family. J.N.Am.Benthol.Soc., $15: 232-253$.

Bowman M.F. \& Bailey R.C. 1997. — Does taxonomic resolution affect the multivariate description of the structure of freshwater benthic macroinvertebrate communities? Can. J. Aquat. Sci., 54 : 1802-1807.

Falniowski A. 1980. - The anatomical determination of Polish Lymnaeidae (Mollusca, Basommatophora). Acta Hydrobiol., 22 : 327-335.

Germain L. 1931. - Mollusque terrestres et fluviatiles. in Lechevalier (ed.), Faune de France. Librairie de la Faculté des Sciences Paris, 21-22: $897 \mathrm{p}$.

Glöer P. \& Meier-Brook C. 1994. - Süsswassermollusken. Ein Bestimmungsschlüssel für die Bundesrepublik Deutschland. DJN (ed.) Hamburg : $136 \mathrm{p}$.

ISO. 1979. - Assessment of the biological quality of rivers by a macroinvertebrate 'score'. ISO/TC 147/SC5/WG 6 N $5: 18$ p.

Kolkwitz R.\& Marsson M. 1909. - Ökologie der tierischen Saprobien. Beiträge zur Lehre von der biologischen Gewässerbeurteilung. Internat.Rev.Hydrobiol., $2: 126-152$.

Mouthon J. 1981. - Typologie des mollusques des eaux courantes. Organisation biotypologique et groupements socioécologiques. Annls Limnol., 17 (2) : 143-162.

Mouthon J. 1994. — Fréquences et densité des espèces de mollusques dans les cours d'eau français. Vertigo, $4: 19-28$.

Mouthon J. 1996. - Molluses and biodegradable pollution in rivers : proposal for a scale of sensitivity of species. Hydrobiologia, 317 : 221-229.

Mouthon J. 1999. - Longitudinal organisation of mollusc species of a theoretical French river. Hydrobiologia., (in press).

Nagel von P. 1989. - Bildbestimmungschliussel der Saprobien. Makrozoobenthon. G.Fischer Verlag., Stuttgart : 183 p.

Resh H. \& McElravy E.P. 1993. - Contemporary quantitative approaches to biomonitoring using benthic macroinvertebrates. In Freshwater biomonitoring and benthic macroinvertebrates. D.M. Rosenberg \& V.C. Resh (eds). London 5 : 159-194.

Slàdecek V. 1973. - System of Water Quality from the Biological Point of View. Arch. Hydrobiol. Beih. Ergebn. Limnol., 7 : 1-218.

Verneaux J. 1982. — Une nouvelle méthode pratique d'évaluation de la qualité des eaux courantes. Un indice biologique de qualité générale (I.B.G.). Ann. Sci. Univ. F-C. Besançon 3 : 11-21.

Willmann R. \& Pieper H. 1978. - Gastropoda In : J. Illies (ed.), Limnofauna Europaea. G. Fischer Verlag, Stutgart : $118-134$. 